\title{
Antibacterial and Cytotoxic Actions of Chloroform Crude Extract of Leptadenia hastata (Pers) Decnee
}

Isaac John Umaru*, Fasihuddin Ahmad Badruddin, Zaini B Assim and Hauwa Aduwamai Umaru

Department of Biochemical Science, Universiti Malaysia Sarawak, Kota Samarahan, Malaysia

*Corresponding author: Isaac John Umaru, MSc, Universiti Malaysia Sarawak, Kota Samarahan Malaysia, Kuching, Sarawak, Malaysia, Tel: +6082581009; E-mail: umaruisaac@gmail.com

Rec date: January 03, 2018; Acc date: January 05, 2018; Pub date: January 11, 2018

Copyright: () 2018 Umaru IJ, et al. This is an open-access article distributed under the terms of the Creative Commons Attribution License, which permits unrestricted use, distribution, and reproduction in any medium, provided the original author and source are credited.

\begin{abstract}
Objective: The study presented here was carried out for the evaluation of bacterial and cytotoxic potential of chloroform extract of Leaves of Leptadenia hastata. The Bacterial effects was tested against 4 bacteria namely Salmonella typhi, Escherichia coli, Staphylococcus aureus, and Klebsielia pneumonia.

Methods: The bacterial effect of the plant Leptadenia hastata was evaluated for potential antimicrobial properties in vitro by agar well diffusion method with four standard bacterial strains. Artemia salina; a brine shrimp species; was used to asses' cytotoxic activity of the plant extract.
\end{abstract}

Result: Among the subjected four bacteria; in case of Staphylococcus aureus, E. coli and Salmonella typhi; their zone of inhibition was higher $(1.13 \pm 0.15,1.23 \pm 0.12$ and $1.03 \pm 0.06)$ at 1000 ppm concentration. Whereas in the case of Klebsielia pneumonia, the zone of inhibition was higher $(1.13 \pm 0.06)$ at 500 ppm. The extract exhibited effectiveness against the four species of bacteria was significant. Cytotoxicity property which was reflected in LC50 value and was found to be dose dependent manner

Conclusion: The present results showed potential of the medicinal plant used by traditional herbal medical practitioners as natural anti-bacteria and can effectively be used for its significant action. It is also an effective cytotoxic agent and thus justify its use among herbal medical practitioners.

Keywords: Leptadenia hastate, Brine shrimps; Bacteria; Chloroform

\section{Introduction}

Infectious disease remains a major public health problem throughout the world [1]. Pharmacological industries have produced many new antibiotics in the last three decades, but still resistance to these drugs by microorganisms has increased. In general, bacteria have the genetic ability to transmit and acquire resistance to drugs, which are utilized as therapeutic agents [2].

However, nature has blessed us with various herbs which are enriched with nutrient as well as medicinal values. For centuries, the purpose of food as well as medicine is served using herbs. Various herbs were in focus of research interest that possess anti-bacterial, antiulcer, anti-tumor, anti-diabetic properties that may be of use in adjuncts in helping the risk of diseases and ailments [3].

Most important effects of these herbs are because of compounds, such as alkaloids, tannins, flavonoids, terpenoids, saponins, and phenolic compounds [4]. The herbs are now in great demand in the developing world for primary health care not because they are inexpensive but because of their therapeutic, performance, better compatibility and acceptability with human body with low toxicity and minimal side effects [5].

The World Health Organization (WHO) estimates that $80 \%$ of the total population of some Asian and African countries, even the world at large are presently uses herbal medicine for some aspects of primary health care which must compound derive from medicinal herbs [6].

Even as many plants are used traditionally for their antimicrobial properties, which results from the phytochemicals present in these plants. The plant Leptadenia hastata is one of such plants with antibacterial potentials.

Leptadenia hastata (pers) Decne is a perennial plant of the family of Asclepediacea, the plant is edible non-domesticated vegetable and it is collected in wild throughout Africa. It is a voluble herb with creeping latex stems, glabescent leaves, glomerulus and racemes flowers as well as follicle fruits, the leaves are up to $10 \mathrm{~cm}$ long, mostly ovate and light green. The flowers are cream or yellowish-green [7]. The vernacular names Leptadenia hastata include; hagalhadjar in Arabic and in chad, yadiya in Nigeria and Niger, while in Kusum hyala in Ethiopia. Ekamongo from Turkina in Kenya. Moore people call it mlolongo in Burkina Faso, Darhat from Wolof in busumba, amata from Jola in Senegal and Bambara's call it nzongne in Mali [8]

The plant is a very drought-resistance plant and can grow with $100-450 \mathrm{~mm}$ per year. It can tolerate high $\mathrm{pH}$ and high exchangeable sodium and potassium with the environment [9]. The leaves are edible, young leaves are collected washed and cooked before consumption. Farmers deliberately grow the species in their homes as food readily available [10]. Local healers use the plant for hypertension, catarrh and skin diseases [11]. The breeders commonly used the leaf and the stems for the treatment of parasites and against placental retention among their animals $[12,13]$. 
The plant of this genus is also known to be useful in anti-gonorrhea, stomach ache, hypertension, catarrh, skin diseases, wound healing [14-19].

\section{Materials and Methods}

\section{Chemicals}

All chemicals used in this investigation were of analytical grade and were obtained from SIGMA. Standard antibacterial agent $(30 \mu \mathrm{g})$ tetracycline, antimicrobial susceptibility test discs and Nutrient agar (CM0003) were obtained from Oxoid Ltd, Wade Road, Basingstoke, Hants, RG2 8PW, UK.

\section{Preparation of test samples}

The crude extracts of Leptadenia hastata was used in antibacterial assay, the chloroform crude extracts. The crude extracts were tested by disc diffusion method on nutrient agar medium as described by Pundir and Jain [20]. Exactly $3 \mathrm{mg}$ of the crude sample was dissolved homogeneity in $3 \mathrm{~mL}$ of methanol giving a stock solution of $1000 \mu \mathrm{g} /$ $\mathrm{mL}$. Different volumes from the stock solution were taken, amounted to $25,50,100,250,500,1000 \mathrm{ppm}$ each, and dissolved in $5 \mathrm{~mL}$ of methanol to make final concentration respectively.

\section{Preparation of agar plates}

Preparation of agar plates was performed based on method described by Pundir and Jain [20]. Nutrient agar was prepared according to manufacturer's instruction with $14 \mathrm{~g}$ of dried agar dissolved in $500 \mathrm{~mL}$ distilled water. The agar solution was heated until boiling followed by sterilization in autoclave at $121^{\circ} \mathrm{C}$. The agar solution was then poured into a sterile petri plate and allowed to cool down and forming a gel. The plate was divided into eight sections by making a line marking on the outside surface of the plate. The eight sections were for each test samples namely the 25,50,100, 250, 500, $1000 \mathrm{ppm}$ samples, tetracycline $30 \mu \mathrm{g}$ (positive control) and methanol (negative control). The plate was sealed using parafilm and keep chilled at $4^{\circ} \mathrm{C}$ upon bacteria inoculation.

\section{Preparation of bacteria broth}

Several selected bacteria were used to evaluate the antibacterial activities of the crude extracts of Leptadenia hastate, Escherichia coli (ATCC@25922), Salmonella typhi, (ATCC@14028), Staphylococcus aureus (ATCC@25923) and Kliebselia pneumonia, (ATCC@19155) were obtained from the stock culture provided by Virology Laboratory, Universiti Malaysia Sarawak, the nutrient broth was prepared according to manufacturer's instruction, with $2.6 \mathrm{~g}$ of the dried broth dissolved in $200 \mathrm{~mL}$ distilled water followed by sterilization in autoclave at $121^{\circ} \mathrm{C}$. The bacterial was sub-cultured in a $10 \mathrm{~mL}$ of broth, each in universal glass bottle for 16 hours inside an incubator equipped with shaker at $37^{\circ} \mathrm{C}$ [21]. After 16 hours incubation, turbidity (optical density/OD) of the bacterial broth was measured by using UV mini spectrophotometer (model 1240 of Shimadzu brand), comparable to that of nutrient broth standard tube for further use [22]. Measurement was performed at wavelength $575 \mathrm{~nm}$ and the bacterial broth was ready to be used when its turbidity was between OD 0.6 to 0.9 . Nutrient broth was used to adjust the turbidity until the desired value was obtained.

\section{Plate inoculation}

Inoculation of the bacteria was carried out in a biohazard cabinet and the procedure was based on method described by Pundir and Jain [20]. Approximately $1 \mathrm{~mL}$ of the ready bacterial broth were transferred into mini centrifuge tubes. A sterile cotton swap was dipped into the mini centrifuge tube containing bacteria broth and streaked over entire of the agar plate surface, performed in 4 different directions. The agar plate was then left for 5-10 minutes before applying the test samples. The disc used was $6 \mathrm{~mm}$ diameter. A volume of $10 \mu \mathrm{L}$ of the test samples of concentration 25,50,100,250, 500, $1000 \mathrm{ppm}$ were each pupated onto the discs and placed onto the agar plate by using sterile forceps and gently pressed to ensure contact. Next to be placed on the agar plate was the disc pupated with methanol as negative control, followed by $30 \mu \mathrm{g}$ of tetracycline as standard antibacterial agent (positive control). The plates were left at room temperature for 10 minutes to allow the diffusion of the test samples and the standards into the agar. Each crude extract was tested in triplicate for each bacterium used. The plate samples were then incubated at $37^{\circ} \mathrm{C}$ for 24 hours before the inhibition zone around every sample disc being examined. The inhibition zone was measured in diameter to indicate the presence of antibacterial activity for each sample, as compared to the positive control.

\section{Results}

The results of antibacterial sensitivity assay of the six concentration of chloroform extract of Leptadenia hastata are presented in Table 1. The antibacterial activities were observed in various ways with zone of inhibition diameters ranging from $0.47 \pm 0.15 \mathrm{~mm}$ to $1.23 \pm 0.12 \mathrm{~mm}$. Among the six-concentration selected $(25,50,100,250,500$, and 1000 ppm) 1000 ppm was the most active. It showed the highest zone of inhibition, the concentration inhibited the growth of all the tested bacteria with zone of inhibition ranging from $1.03 \pm 0.06$ for Salmonella typhi, $1.13 \pm 0.15$ for Staphylococcus aureus and Escherichia coli with $1.23 \pm 0.12 \mathrm{~mm}$ whereas the concentration was less active on Klebsielia pneumonia with zone of inhibition $1.07 \pm 0.21$ $\mathrm{mm}$ when compared with the zone of inhibition at $500 \mathrm{ppm} 1.13 \pm$ 0.06 .

The extract of chloroform of Leptadenia hastata were active against Staphylococcus aureus, Escherichia coli, Salmonella typhi and Klebsielia pneumonia within increase in concentration when compared with the control tetracycline. Among the tested bacterial Salmonella typhi was the less sensitive as shown in Table 1. Tetracycline which was used as a positive control, had zones of inhibition diameters ranging from $2.04 \pm 0.01 \mathrm{~mm}$ to $2.05 \pm 0.02 \mathrm{~mm}$. DMSO which was used as the negative control showed no activity.

\begin{tabular}{|l|l|l|l|l|l|l|l|}
\hline \multicolumn{7}{|l|}{ Concentration (ppm) } \\
\hline Bacteria & Control & $\mathbf{2 5}$ & $\mathbf{5 0}$ & $\mathbf{1 0 0}$ & $\mathbf{2 5 0}$ & $\mathbf{5 0 0}$ & $\mathbf{1 0 0 0}$ \\
\hline Staphylococcus aureus & $2.04 \pm 0.01$ & $0.67 \mathrm{a} \pm 0.06$ & $0.80 \mathrm{a} \pm 0.10$ & $0.90 \mathrm{a} \pm 0.20$ & $1.03 \pm 0.12$ & $1.03 \pm 0.06$ & $1.13 \pm 0.15$ \\
\hline
\end{tabular}


Page 3 of 4

\begin{tabular}{|l|l|l|l|l|l|l|l|}
\hline Escherichia coli & $2.05 \pm 0.02$ & $0.47 \pm 0.15$ & $0.73 \pm 0.06$ & $0.83 \pm 0.06$ & $1.00 \pm 0.10$ & $1.07 \pm 0.06$ & $1.23 \pm 0.12 \mathrm{a}$ \\
\hline Salmonella typhi & $2.04 \pm 0.06$ & $0.57 \pm 0.06$ & $0.67 \pm 0.06$ & $0.70 \pm 0.10$ & $0.93 \pm 0.06$ & $0.93 \pm 0.06$ & $1.03 \pm 0.06$ \\
\hline Klebsielia pneumonia & $2.05 \pm 0.02$ & $0.63 \pm 0.06$ & $0.70 \pm 0.17$ & $0.83 \pm 0.06$ & $1.03 \pm 0.12 \mathrm{a}$ & $1.13 \pm 0.06 \mathrm{a}$ & $1.07 \pm 0.21$ \\
\hline
\end{tabular}

Table 1: Effects of chloroform leaf extract of Leptadenia hastata on Salmonella typhi, Escherichia coli, Staphylococcus aureus, and Klebsielia pneumonia. Values are Mean \pm SD for three determinations a significantly $(\mathrm{p}<0.05)$ higher compared to the same concentration and lower compared to the positive control.

\section{Cytotoxic activity}

The Brine shrimp results presented (Table 2) show that the leaf extracts were virtually non-toxic on the shrimps. They exhibited very low toxicity at $1 \mathrm{ppm}-500 \mathrm{ppm}(1 \pm 0.01,1 \pm 0.56,2 \pm 0.00,2 \pm 0.56,2$ $\pm 0.00,3 \pm 0.00$ ) respectively with LC50 $=346 \mu \mathrm{g} / \mathrm{ml}$. Giving the LC50 values greater than $100 \mu \mathrm{g} / \mathrm{ml}$. This only provides a proof of cytotoxic effects of the plant extracts which might suggest a base line information in understanding the potential medicinal value of Leptadenia hastate.

\begin{tabular}{|c|c|c|c|c|c|c|c|}
\hline \multirow[t]{2}{*}{ Sample } & \multicolumn{6}{|c|}{ Number of death of Artemia saline brine Shrimp } & $\operatorname{LC50}(\mu \mathrm{g} / \mathrm{mL})$ \\
\hline & \multicolumn{7}{|c|}{ Concentration $(\mu \mathrm{g} / \mathrm{mL})$} \\
\hline $\begin{array}{l}\text { Crude Extract of Leptadenia } \\
\text { hastata Leaf }\end{array}$ & $1 \mathrm{ppm}$ & 10 ppm & $25 \mathrm{ppm}$ & 50 ppm & 100 ppm & 500 ppm & \\
\hline Chloroform extract & $1 \pm 0.01$ & $1 \pm 0.56$ & $2 \pm 0.00$ & $2 \pm 0.56$ & $2 \pm 0.00$ & $3 \pm 0.00$ & 346 \\
\hline Negative control & 0 & 0 & 0 & 0 & 0 & 0 & - \\
\hline Thymol & $3 \pm 0.57$ & $5 \pm 0.57$ & $6 \pm 0.54$ & $7 \pm 0.57$ & $10 \pm 0.00$ & $10 \pm 0.00$ & 1.16 \\
\hline
\end{tabular}

Table 2: The leaf extracts were virtually non-toxic on the shrimps.

\section{Discussion}

In recent years, the search for medicinal plant possessing antimicrobial activities have been on the rise because of their potential use in ethnomedicine. However, due to risk of adverse effects encountered with the use of synthetic drugs, medicinal plant may offer an alternative source for antibacterial agent with significant activity against resistance strains, pathogen and infective microorganism.

The result of these studies and the Inhibitions observed in the plant extracts were not due to the solvent but rather was because of some of the phytochemical components extracted by the chloroform such as tannins, saponins, terpenoids, alkaloids, flavonoids, phenols and steroids which were inculpated in the pharmacological properties of the plant species [23]. Leptadenia hastata was reported to contain tannins, saponins, terpenoids, alkaloids, flavonoids, phenols and steroids [24].

Thus, the bacterial activities observed can be because of the presence of these components. In agreement with the work of [6], found that the aqueous extract of Leptadenia hastata has inhibitory effects against bacteria's. Thus, strong antibacterial activities and cytotoxic specifically in this polar extract of chloroform played a role in the inhibition rate observed. It is also an effective cytotoxic agent and thus justify its use among herbal medical practitioners. Thus, because of the huge concern of resistance antibiotic, it becomes important to identify new bio active antimicrobial agents to replace antibiotics. Therefore, this study presents new antimicrobial plant extracts that could be potential therapeutics in future.

\section{Conclusion}

The chloroform extract of the leaves of Leptadenia hastata have indicated varied levels of antibacterial activities. The concentration of the plant extracts at various concentration level exhibited very low cytotoxicity activity on Brine shrimps. Chloroform leaf extract of the plant Leptadenia hastata have a reasonable potential as antimicrobial compounds against microorganisms especially in the case of Staphylococcus aureus and E. coli with increase in concentration. Thus, the plant extracts can be used as a novel drug against the development of resistance strains, mostly through the expression of resistance genes they can be used in the treatment of infectious diseases caused by resistance bacterial.

\section{Acknowledgement}

The author acknowledged the contribution of colleagues and all supports from the Natural product laboratory FRST/FSTS UNIMAS.

\section{Conflict of Interests}

All authors have none to declare.

\section{References}

1. Hoekou PY, Tchacondo T, Gbogbo KA, Tchelougou D, Pissang P, et al. (2015) Antibacterial activities of three latex plants of Asclepiadaceae family used in traditional medicine in South Togo. Int J Curr Microbiol App Sci 4: 882-891.

2. Cohen ML (1992) Epidemiology of drug resistance: implications for a post-antimicrobial era. Science(Washington) 257: 1050-1055. 
Citation: Umaru IJ, Badruddin FA, Assim ZB, Umaru HA (2018) Antibacterial and Cytotoxic Actions of Chloroform Crude Extract of Leptadenia hastata (Pers) Decnee. Clin Med Biochem 4: 139. doi:10.4172/2471-2663.1000139

Page 4 of 4

3. Craig WJ (1999) Health-promoting properties of common herbs. The American Journal of Clinical Nutrition 70: 491s-499s.

4. Cook NC, Samman S (1996) Flavonoids-chemistry, metabolism, cardioprotective effects, and dietary sources. The Journal of Nutritional Biochemistry 7: 66-76.

5. Akhtar N, Mirza B (2015) Phytochemical analysis and comprehensive evaluation of antimicrobial and antioxidant properties of 61 medicinal plant species. Arabian Journal of Chemistry.

6. Manandhar NP (2002) Plants and people of Nepal. Timber Press.

7. Aliero AA, Wara SH (2009) Validating the medicinal potential of Leptadenia hastata. African Journal of Pharmacy and Pharmacology 3: 235-238.

8. Thomas SD (2012) Leptadenia hastata: A Review of its Traditional uses and its Pharmacological Activity. Med Chem 2: 148-150.

9. Afifi MS, Hassan MA, Ali EA, Badria FA, Mahmood EF (2002) Phytochemical and Biological investigation of Leptadenia Pyrotechnica decne growing in Egypt. Journal of Pharmaceutical Sciences 18: 122-138.

10. Freiberger CE, Vanderjagt DJ, Pastuszyn A, Glew RS, Mounkaila G, et al. (1998) Nutrient content of the edible leaves of seven wild plants from Niger. Plant Foods for Human Nutrition (Formerly Qualitas Plantarum) 53: 57-69.

11. Dambatta SH, Aliyu BS (2011) A survey of major ethno medicinal plants of kano north, Nigeria, their knowledge and uses by traditional healers. Bayero Journal of Pure and Applied Sciences 4: 28-34.

12. Bayala B, Telefo PB, Bassole IHN, Tamboura HH, Belemtougri RG, et al. (2011) Anti-spermatogenic activity of Leptadenia hastata (Pers.) Decne leaf stems aqueous extracts in male wistar rats. Journal of Pharmacology and Toxicology 6: 391-399.

13. Arbonnier M (2000) Arbres, Arbustes et Lianes des Zones Sèches d'Afrique de l'Ouest. 1st Edn, CIRAD Publishers, Paris p: 541.

14. Mohammed MI, Sharif N (2011) Mineral composition of some leafy vegetables consumed in Kano, Nigeria. Nigerian Journal of Basic and Applied Sciences 19

15. Burkill HM (1994) The useful plants of west tropical Africa. Vol 2: Families (Edition 2). Royal Botanic Gardens.
16. Bello A, Aliero AA, Saidu Y, Muhammad S (2011) Hypoglycaemic and hypolipidaemic effects of Leptadenia hastata (Pers) Decne in alloxan induced diabetic rats. Nigerian Journal of Basic and Applied Sciences 19: 187-192.

17. Mathieu G, Meissa D (2007) Traditional leafy vegetables in Senegal: Diversity and medicinal uses. African Journal of Traditional, Complementary and Alternative Medicines 4: 469-475.

18. Nikiema JB, Vanhaelen-Fastré R, Vanhaelen M, Fontaine J, De Graef C, et al. (2001) Effects of antiinflammatory triterpenes isolated from Leptadenia hastata latex on keratinocyte proliferation. Phytotherapy Research 15: 131-134.

19. Tamboura HH, Bayala B, Lompo M, Guissoe IP, Sawadogo L (2006) Ecological distribution, morphological characteristics and acute toxicity of aqueous extracts of holarrhena floribunda (g. don) durand \& schinz, leptadenia hastata (pers.) decne and cassia sieberiana (dc) used by veterinary healers in burkina FASO. African Journal of Traditional, Complementary and Alternative Medicines (AJTCAM) 2: 13-24.

20. Pundir RK, Jain P (2010) Comparative studies on the antimicrobial activity of black pepper (Piper nigrum) and turmeric (Curcuma longa) extracts. International Journal of Applied Biology and Pharmaceutical Technology 1: 491-501.

21. Mahesh B, Satish S (2008) Antimicrobial activity of some important medicinal plant against plant and human pathogens. World Journal of Agricultural Sciences 4: 839-843.

22. Vandepitte J, Engback K, Piot P, Heuck CC (1995) Basic Microbiology Procedures in Clinical Bacteriology. Geneva: World Health Organization p. 85 .

23. Alagesaboopathi C (2013) Evaluation of antibacterial properties of leaf and stem extracts of Andrographis elongata T. And.-An endemic medicinal plant of India. Int J Pharm Bio Sci 4: 503-510.

24. Thomas SD (2012) Leptadenia hastata: A Review of its Traditional uses and its Pharmacological Activity. Med Chem 2: 148-150. 